\title{
QUEEN'S
UNIVERSITY
BELFAST
}

\section{The Role of Personality Factors in the Reduction of Intergroup Anxiety and Amelioration of Outgroup Attitudes via Intergroup Contact}

Turner, R. N., Dhont, K., Hewstone, M., Prestwich, A., \& Vonofakou, C. (2014). The Role of Personality Factors in the Reduction of Intergroup Anxiety and Amelioration of Outgroup Attitudes via Intergroup Contact. European Journal of Personality, 28(2), 180-192. https://doi.org/10.1002/per.1927

Published in:

European Journal of Personality

Document Version:

Peer reviewed version

Queen's University Belfast - Research Portal:

Link to publication record in Queen's University Belfast Research Portal

\section{Publisher rights}

Copyright @ 2013 John Wiley \& Sons, Ltd.

This is the accepted version of the following article: Turner, R. N., Dhont, K., Hewstone, M., Prestwich, A. and Vonofakou, C. (2014), The Role of Personality Factors in the Reduction of Intergroup Anxiety and Amelioration of Outgroup Attitudes via Intergroup Contact. Eur. J. Pers., 28: 180-192. doi: 10.1002/per.1927, which has been published in final form at

http://onlinelibrary.wiley.com/doi/10.1002/per.1927/abstract;jsessionid=CC86C181BFB6AB8D7A8307CA0D4C9981.f01t03.

\section{General rights}

Copyright for the publications made accessible via the Queen's University Belfast Research Portal is retained by the author(s) and / or other copyright owners and it is a condition of accessing these publications that users recognise and abide by the legal requirements associated with these rights.

Take down policy

The Research Portal is Queen's institutional repository that provides access to Queen's research output. Every effort has been made to ensure that content in the Research Portal does not infringe any person's rights, or applicable UK laws. If you discover content in the

Research Portal that you believe breaches copyright or violates any law, please contact openaccess@qub.ac.uk. 
Running Head: CONTACT AND PERSONALITY PREDICTORS

The role of personality factors in the reduction of intergroup anxiety and amelioration of outgroup attitudes via intergroup contact

\author{
Rhiannon N. Turner ${ }^{1}$ \\ Queen's University Belfast, UK
}

Kristof Dhont ${ }^{2}$

Ghent University, Belgium

Miles Hewstone

University of Oxford, UK

Andrew Prestwich

University of Leeds, UK

Christiana Vonofakou

University of Oxford, UK

KEYWORDS: CROSS-GROUP FRIENDSHIPS, EXTRAVERSION, OPENNESS TO

EXPERIENCE, AGREEABLENESS, INTERGROUP ANXIETY

\begin{abstract}
AUTHOR NOTES
${ }^{1}$ Correspondence regarding this paper should be addressed to Rhiannon Turner, School of Psychology, Queen's University Belfast, Belfast BT7 1NN. Tel: 02890974352. Email:

r.turner@qub.ac.uk

${ }^{2}$ Kristof Dhont is a post-doctoral researcher supported by the Research Foundation - Flanders (FWO, Belgium).
\end{abstract}




\begin{abstract}
Two studies investigated the role of personality factors in the amelioration of outgroup attitudes via intergroup contact. In study 1 , the effect of extraversion on outgroup attitudes operated via an increase in cross-group friendship, whereas openness to experience and agreeableness had a direct effect on outgroup attitudes. In study 2, we included intergroup anxiety as a mediator explaining these relationships, and we ruled out ingroup friendship as a potential confound. We found that the relationships between openness to experience and agreeableness on the one hand, and outgroup attitudes on the other, were mediated by reduced intergroup anxiety. In addition, the effect of extraversion on outgroup attitudes operated via an increase in cross-group friendship which was in turn associated with lower levels of intergroup anxiety. Across both studies, the friendship - attitude relationship was stronger among those low in agreeableness and extraversion. We discuss the importance of integrating personality and situational approaches to prejudice reduction in optimizing the impact of contact-based interventions.
\end{abstract}


The role of personality factors in the reduction of intergroup anxiety and amelioration of outgroup attitudes via intergroup contact

The contact hypothesis proposes that positive encounters between members of different groups lessen intergroup prejudice, an idea that has received extensive empirical support (Allport, 1954; Pettigrew \& Tropp, 2006). Recent research has recognised cross-group friendship as an especially effective form of contact (Pettigrew, 1997), and has identified intergroup anxiety as a key mediator of the friendship - attitude relationship (e.g., Brown \& Hewstone, 2005; Pettigrew \& Tropp, 2008; Prestwich, Kenworthy, Wilson, \& Kwan-Tat, 2008). Contact is one of the most important and well-supported situational approaches to prejudice, but despite the general conclusion that both situational and personality influences combine in bringing about psychological outcomes and behaviour (Kenrick \& Funder, 1988), integration of the two approaches in the investigation of intergroup relations is rare. Hodson (2009) stated that 'Nowhere is the theoretical divide between person and situation more evidence than in the domain of prejudice research' (p. 247). This is especially the case regarding the contact hypothesis, with most researchers ignoring or controlling individual differences as nuisance variables (Hodson, 2008).

The present studies extend research and theory in three important ways. First, we emphasise the importance of integrating personality and situational approaches by highlighting that some of the 'big five' personality variables (e.g., Goldberg, 1992; McCrae \& Costa, 1999) specifically, openness to experience, agreeableness, and extraversion - influence cross-group friendship and its consequences. To our knowledge, this is the first study to specifically investigate the role of either friendship or extraversion in predicting outgroup attitude. Second, we demonstrate that intergroup anxiety, a key process underlying the relationship between cross-group friendships and outgroup attitude, is influenced by personality variables. Third, we examine whether the relationship between contact, intergroup anxiety, and outgroup attitude is stronger for those with personality traits associated with low levels of intergroup contact and negative intergroup attitudes. Below we describe research on cross-group friendship and its mediating 
processes, before outlining how intergroup contact theory and personality theory can, and should, be integrated.

Cross-group friendship and intergroup anxiety

Pettigrew (1997) demonstrated that cross-group friendships between members of dominant national groups and ethnic minorities are associated with reduced ethnic prejudice (for a metaanalysis see Davies et al., 2011). Longitudinal research has also shown that, over time, students who have more cross-group friendships had more favourable orientations towards ethnic outgroups (Levin, van Laar, \& Sidanius, 2003; Swart, Hewstone, Christ, \& Voci, 2011). Pettigrew and Tropp's (2006) meta-analysis compared the effect size for reduced prejudice between tests using cross-group friendships as predictor variables versus other types of contact, and found that crossgroup friendships yielded a substantially stronger effect in reducing prejudice.

Intergroup anxiety (Stephan \& Stephan, 1985), the negative arousal that can arise when anticipating an interaction with an outgroup member, has emerged as the most important mediator of the relationship between cross-group friendship and outgroup attitude (Pettigrew \& Tropp, 2008). It can lead to a narrowing of attention, which in turn can result in simplified, expectancyconfirming processing and a reliance on stereotypes when evaluating outgroup members (e.g., Wilder, 1993; Wilder \& Simon, 2001). Intergroup anxiety is most likely to arise where there has been little previous contact with the outgroup and when there are large differences in status (Stephan \& Stephan, 1985). Friendship-based interaction is, however, likely to be associated with intimate sustained contact and, at least within the contact situation, is likely to be characterized by equal status. It should therefore hold the opposite of these anxiety-predicting characteristics. Accordingly, several studies (e.g., Paolini, Hewstone, Cairns, \& Voci, 2004; Swart et al., 2011; Turner, Hewstone, \& Voci, 2007) show that reduced anxiety mediate the positive relationship between cross-group friendship and outgroup attitude. 
Combining intergroup contact theory with personality theory

A diversity of approaches is generally thought to be crucial for the discovery of new knowledge (Cronbach, 1986), and integrative approaches are assumed to lead to new theoretical advances and may offer practical approaches to reducing or limiting destructive patterns of intergroup relations (Mackie \& Smith, 1998). Accordingly, Jackson and Poulsen (2005) argue for an integration of personality characteristics and situational determinants when studying intergroup contact in order to provide a more complete understanding of strategies needed to reduce prejudice. According to the dynamic interactional strategy, behavioural consistency is the product of the reciprocal causal relation between personality and the environment, with people tending to enter and participate in situations that are most conducive to the behavioural expression of their traits (Ickes, Snyder, \& Garcia, 1997). Nevertheless, there has been relatively little integration of personality and situational approaches in studies of prejudice, and, more particularly, in studies of the contact hypothesis, with most contemporary approaches to prejudice reduction rooted in situationalism (Hodson, 2009).

The main exception to this is research which links right-wing authoritarianism (RWA, Altemeyer, 1988; see Adorno et al., 1950) and social dominance orientation (SDO, Pratto, Sidanius, Stallworth, \& Malle, 1994) to intergroup contact and prejudice. People high in these traits tend to be more prejudiced, and are also less likely to engage in contact. Pettigrew (2008), for example, found that authoritarians are less likely to live in an area with foreigners, engage in contact even if they do live in such areas, or form cross-group friendships. Nonetheless, these individuals are particularly susceptible to the effects of positive intergroup contact when it does arise. Dhont and Van Hiel (2009) demonstrating that there was a stronger negative relationship between positive contact with immigrants and racism towards immigrants among people high in SDO and RWA (see also Hodson, 2008; Hodson, Harry, and Mitchell, 2009). Asbrock, Christ, Duckitt, and Sibley (2012) found evidence to suggest that this effect is strongest for those high in 
RWA, because RWA is caused by perceptions of symbolic threat, something which intergroup contact has been shown to be effective at reducing (e.g., Stephan et al., 2000).

Increasingly, however, there has been criticism of research that focuses on SDO and RWA as personality predictors of prejudice. Sibley and Duckitt (2008) argue that in contrast to personality scales, the items that make up the SDO and RWA scales do not refer to generalised behavioural dispositions, but instead to social attitudes and beliefs that express ideological values. In other words, they might be described as measures of enduring beliefs rather than fixed personality traits. Indeed, SDO and RWA are more strongly correlated with other measures of attitudes and values rather than behaviour (Duriez \& Van Hiel, 2002; Duckitt \& Sibley, 2010). Accordingly, Jackson and Poulsen (2005) have argued that it may be more useful to study the relationship between personality and prejudice in terms of the five-factor model of personality.

The Five-Factor Model of Personality and Prejudice

The five factor model of personality (FFM; e.g., Goldberg, 1992) is a widely accepted approach to conceptualizing and assessing personality traits, with extensive empirical evidence supporting its basic propositions (McCrae \& Costa, 1999). Five major dimensions of personality are assumed to sufficiently summarise the most important aspects of personality. Extroverts tend to be talkative, sociable, and fun-loving; agreeable people tend to be sympathetic, warm, and cooperative; people who are high on openness to experience tend to exhibit such attributes as imagination, broad interests, and nonconformity; conscientious people tend to be ethical, dependable, and purposeful; while neurotic individuals are usually anxious, insecure, and selfconscious.

Recently, openness to experience and agreeableness have been considered as determinants of intergroup attitudes and stereotypes (Duckitt \& Sibley, 2010; Sibley \& Duckitt, 2008). Flynn (2005) found that majority group members who scored highly on these traits were more likely to be influenced by stereotype-disconfirming information about minority group members, Ekehammar and Akrami (2003) found that openness to experience and agreeableness were 
strongly negatively correlated with generalised prejudice, while Akrami, Ekehammar, and YangWallentin (2011) recently found that a combination of social psychological factors (gender group membership and identification) and personality factors (openness to experience, agreeableness, SDO and RWA) was more predictive of sexism than each type of factor in isolation.

Sibley and Duckitt (2008) offer an explanation for these effects. They note that people who are low in openness are more likely to identify with the existing social order, and the values and beliefs associated with it, because it provides a normative referent for the way things are meant to be, enabling them to see the world in a clear and unambiguous way. When they encounter an outgroup, which is perceived as holding a different set of values and norms, they are likely to perceive members of that group as threatening, which in turn is likely to predict an increase in prejudice. People who are low in agreeableness are likely to pursue goals that will enhance their own interests, with little concern for any conflict this might create with the interests of others. They tend to see the world as a socially competitive place where the most powerful succeed, and are therefore likely to exhibit a heightened motivation for group based dominance and superiority, which in turn is likely to be associated with higher levels of prejudice.

\section{Intergroup Contact and the Five-Factor Model of Personality}

As far as we are aware, only Jackson and Poulsen (2005) have previously sought to integrate personality and situational approaches to prejudice by applying the FFM and the contact hypothesis to the study of prejudice. Their model was concerned with how personality traits influence situational evocation and selection. The concept of situational evocation postulates that people, because of their personalities, change the social situations they are in through their presence (Buss, 1989), while the basic idea of situational selection is that personality characteristics affect which situations people seek out (Ickes et al., 1997). Jackson and Poulsen proposed that people high on openness and agreeableness will be more likely to seek out favourable intergroup contact experiences (situational selection) and be more likely to act in a way that facilitates favourable interactions (evocation). These experiences are then assumed to have an 
effect on prejudiced attitudes. Their results, in the form of two separate regression analyses, showed that openness was related to both frequency and quality of contact, whereas agreeableness was related to quality but not frequency. Furthermore, contact was found to be a significant and independent predictor of attitudes, and each relationship between a personality trait and outgroup attitudes was significantly mediated by contact experiences.

Following the general premise of Jackson and Poulsen's study, the intention of the present research was to integrate relevant FFM traits of personality with cross-group friendship in order to evaluate the relative impact of personality and situational factors on outgroup attitudes. Previous research suggests that openness to experience and agreeableness are the most reliable trait predictors of outgroup attitude (Ekehammar \& Akrami, 2003; Jackson \& Poulsen, 2005; Sibley \& Duckitt, 2008). In addition, however, we investigated whether extraversion is linked to cross-group friendship. Extraversion is particularly relevant in the current research because we focused specifically on the role of personality in predicting cross-group friendship rather than more casual forms of contact. The typical extravert is characterized as someone who is sociable, likes parties, and has many friends. There is evidence that the higher one scores on extraversion, the more friends one has in general (e.g., Eddy \& Sinnett, 1973). Moreover, extraversion is associated with positive peer relations among adolescents, especially concerning peer acceptance or popularity and friendship promotion (Jensen-Campbell \& Graziano, 2001). In other words, extraverts tend to be good at interacting with others, and may be especially adept at ensuring that social interactions are smooth and successful. It follows that if extraversion increases the number and success of friendships generally, it should also increase the probability of having cross-group friendships. Being motivated to satisfy the need for affiliation may be so prominent that extraverts may not be so concerned with differentiating in-group from cross-group friendships. Given that the construct of extraversion is primarily concerned with desire for affiliation with others, rather than social attitudes, we expect extraversion to directly predict cross-group friendship, which in the longerterm might result in more positive outgroup attitudes. In sum, we expected extraversion to predict 
experience of cross-group friendship, and openness and agreeableness to relate to cross-group friendship and outgroup attitudes. Although, to our knowledge, extraversion has not been directly examined as a predictor of friendship, there is some evidence that contact and extraversion may relate to one another. In an investigation of the relationship between intergroup contact and ideology in New Zealand, Sengupta, Barlow and Sibley (2012) controlled for extraversion, and reported a small but significant relationship between extraversion and outgroup contact.

We also examined whether personality plays a role in moderating the effect of cross-group friendship on outgroup attitudes. As noted above, Dhont and Van Hiel (2009, see also Hodson, 2008) found that while those high in SDO and RWA had experienced lower levels of contact and reported higher levels of prejudice, the relationship between contact and reduced prejudice was nonetheless stronger than it was for those low in SDO and RWA. Dhont and Van Hiel note that those high in RWA feel anxious and threatened, whilst those high in RWA lack positive affect towards the outgroup. As contact reduces anxiety and threat, and can induce empathy (e.g., Turner et al., 2007), it follows that those high in RWA and SDO may have the most to gain from positive contact by experiencing reductions in these negative emotions. The low level of prior contact among those individuals may also play a role: recent findings suggest that those with high prior contact experience are less likely to benefit from intergroup contact (Al Ramiah \& Hewstone, 2012). In line with these findings, we hypothesise that contact may be more effective for those low in agreeableness, openness, and extraversion, because these individuals have the most to gain from experiencing intimate contact. We tested our hypotheses in the context of White British nationals' attitudes towards British South Asians - the largest minority group in Britain.

Study 1

Method

\section{Participants}

Participants were 176 undergraduate students at a British university. After excluding all non-White and non-British students, as well as two participants with missing data, the final 
sample was 142 White British students, 81 women and 61 men, with a mean age of 20.21 years $(S D=.80)$.

\section{Procedure}

Participants were informed that the study involved two questionnaires. They were told that the first would be about their experiences with Asians, whereby the term Asian would refer to people of Indian, Pakistani, and Bangladeshi heritage who are living in the UK. Respondents were informed that the other questionnaire assessed characteristics of student populations. To control for order effects, the distribution of both questionnaires, as well as the order of items assessing intergroup contact and outgroup attitudes within one of the questionnaires, was completely counterbalanced. No systematic order effects were detected. After completing both questionnaires all participants were fully debriefed.

\section{Questionnaires}

Predictor Variables. The personality factors of extraversion, openness to experience and agreeableness were measured via the Big Five Inventory (BFI, John, Donohue, \& Kentle, 1991). The 44-item BFI was developed to address the need for a short instrument measuring the prototypical components of the Big Five. As opposed to the commonly used 100-item trait descriptive adjectives (TDA, Goldberg, 1992), the BFI does not employ single adjectives as items because research has shown that answers to such items are less consistent, compared to items accompanied by elaborations or definitions (Goldberg \& Kilkowski, 1985). The BFI employs short phrases, e.g., "is full of energy" (extravert), "has a forgiving nature” (agreeable), to assess the prototypical trait adjectives of the Big Five. Thus, the BFI provides more context than Goldberg's single adjective items.

For each factor, participants indicated the extent to which a series of characteristics applied to them on a 5-point scale $(1=$ strongly disagree, $5=$ strongly agree $)$. Extraversion was measured via eight items, including "Is talkative", "Is full of energy", and "Is outgoing, sociable" $(\alpha=.86)$. Openness to experience was measured via 10 items, including "Is original, 
comes up with new ideas", "Is curious about many different things", and "Is ingenious, a deep thinker". This scale was also reliable $(\alpha=.79)$, but one item, concerned with a preference for work that is routine, only yielded an extremely weak corrected item-total correlation (.11). Thus, we decided to drop this item, which improved the scale reliability $(\alpha=.83)$. Agreeableness was assessed with nine items, including "Is helpful and unselfish with others", and "Likes to cooperate with others". These nine items yielded a reliable scale $(\alpha=.77)$.

To assess the number of cross-group friendships, participants were asked "How many Asian friends do you have?" ( $a=$ None, $b=$ One, $c=$ Two to five, $d=$ Five to ten, $e=$ More than ten). Responses were then coded from 1 (a) to 5 (e), correspondingly. Thus, a higher number denoted more cross-group friendships.

Criterion Variable. Eight items tapped respondents' attitude towards Asians. Participants were asked to complete six bipolar scales (1-7; Warm-Cold (R); Negative-Positive; Friendly-Hostile (R); Suspicious-Trusting; Respect-Contempt (R); Admiration-Disgust (R); Wright, Aron, McLaughlin-Volpe, \& Ropp, 1997). Participants also indicated how often they had felt (a) sympathy, and (b) admiration for Asians $(1=$ never -7 = very often; Pettigrew, 1997). After reversing items marked (R), the items were averaged together yielding a reliable index of outgroup attitude $(\alpha=.82)$. A higher score depicted a more positive attitude towards Asians.

Socio-demographic Variables. Participants indicated their gender, age, nationality, and ethnicity.

\section{Results and Discussion}

\section{Preliminary Analyses}

On average, participants reported having two to five Asian friends $(M=2.90, S D=.92)$. Participants also reported relatively positive scores for outgroup attitude $(M=4.84, S D=.87)$. The average score for extraversion was $3.49(S D=.73), 3.64(S D=.60)$ for agreeableness, and 3. 80 $(S D=.65)$ for openness to experience. 
As can be seen in Table 1, cross-group friendship was positively correlated with outgroup attitude. In line with our hypotheses, extraversion was positively correlated with cross-group friendship, but not with outgroup attitude. Agreeableness and openness to experience were not significantly related to cross-group friendship, but showed a positive relationship with outgroup attitude.

\section{Structural Equation Modeling}

We tested our hypotheses using structural equation modelling (SEM) with latent variables in LISREL using the maximum likelihood estimation procedure (Little, Cunningham, Shahar, \& Widaman, 2002). To smooth measurement error and maintain an adequate ratio of cases to parameters, we applied a partial disaggregation approach (Bagozzi \& Heatherton, 1994). Thus, we created subsets of items resulting in three indicators for extraversion, agreeableness, and openness to experience, as well as for outgroup attitude. Only cross-group friendship was assessed via one indicator. The goodness-of-fit was assessed using the Chi-square test, the comparative fit index (CFI), the root-mean-square error of approximation (RSMEA), and the standardized root-meansquare residual (SRMR). Following standard recommendations, a satisfactory fit is indicated by a Chi-square lower than double the degrees of freedom, a CFI value greater than .95, an RMSEA value of less than .06, and a SRMR value of less than .08 (Hu \& Bentler, 1999).

In the proposed model, extraversion, agreeableness, and openness to experience were entered as predictor variables, followed by cross-group friendship, while outgroup attitude was entered as the sole criterion variable. According to our initial hypotheses, we considered the relationships between the three personality traits and cross-group friendship as well as the associations between openness to experience and agreeableness with outgroup attitude. This structural model yielded a good fit: $\chi^{2}(57)=51.65 .45, p=.68 ; \mathrm{CFI}=1.00 ; \mathrm{RMSEA}=.00 ; \mathrm{SRMR}$ $=.037$. As presented in Figure 1, cross-group friendship had a positive association with outgroup attitude $(\beta=.24, p<.01)$. Extraversion was positively associated with cross-group friendship $\beta=$ $.21, p<.05$, whereas openness to experience and agreeableness were not. Both openness to 
experience and agreeableness were positively related to outgroup attitude, although this relationship was only marginally significant for agreeableness (openness to experience: $\beta=.18$, $p<.05$; agreeableness: $\beta=.17, p<.10$ ). The model explained $15 \%$ of the variance in outgroup attitude $\left(\mathrm{R}^{2}=.15\right)$. In order to identify how much of the variance in outgroup attitudes is explained by personality variables on their own, we ran the model without cross-group friendship and intergroup anxiety. In this case, the variance explained was reduced $\left(\mathrm{R}^{2}=.09\right)$. To summarize, the results of Study 1 showed that extraversion was positively related to cross-group friendship, while openness to experience and agreeableness predicted outgroup attitude. Lastly, cross-group friendship predicted outgroup attitude.

\section{Moderation analyses}

In a final series of analyses we investigated the moderation relationships between the personality traits and cross-group friendships in the prediction of outgroup attitudes. We conducted three regression analyses testing whether the effect of cross-group friendships on outgroup attitudes depends on respondents' levels of agreeableness, extraversion, and openness, respectively. In these analyses, we used the latent factor scores generated by the latent measurement model. We entered the centered scores of each personality factor and cross-group friendships along with their interaction term (i.e., the multiplied centered scores) as predictors of outgroup attitudes, while controlling for the other two personality factors.

Additionally to the results obtained by the SEM analyses, the moderation analyses revealed a significant cross-group friendships $\mathrm{x}$ agreeableness interaction, as well as a significant cross-group friendships $\mathrm{x}$ extraversion interaction on outgroup attitudes, $\beta=-.18, p<.05$ and $\beta=-.18, p<.05$, respectively. The interaction between cross-group friendships and openness was non-significant, $\beta$ $=.05, n s$. Simple slopes analyses indicated that cross-group friendship was significantly related to outgroup attitudes among people scoring low (1 SD below the mean), on agreeableness and among people scoring low on extraversion, $\beta=.36, p<.001$ and $\beta=.37, p<.001$, respectively. This relationship was, however, not significant among high-scorers (1 SD above the mean) on 
agreeableness and extraversion, $\beta=.03$, ns and $\beta=.00, n s$, respectively. For agreeableness and extraversion, these findings therefore support our hypotheses that cross-group friendship would be more effective at generating positive outgroup attitudes among individuals with low scores on these traits.

\section{Study 2}

Although it has not been previously investigated, we predict that the relationships that emerged between all three personality factors and more positive intergroup relations may in part be explained by reduced intergroup anxiety. As in Study 1, we expect extraversion to predict greater cross-group friendship. However, in line with previous findings, the relationship between this increase in cross-group friendships and outgroup attitude should be mediated by reduced intergroup anxiety (e.g., Paolini et al., 2004). By including ingroup friendship in the analysis, we will also be able to rule out the possibility that the relationship between extraversion and crossgroup friendship is simply explained by having more friends in general.

We also expect that while openness and agreeableness may relate to all three intergroup variables (i.e., cross-group friendships, intergroup anxiety, and outgroup attitudes), their relationship with outgroup attitude is likely to be mediated by reduced intergroup anxiety. Our rationale for this is as follows. Open people actively seek out new and varied experiences, and such people are characterized by their non-traditional attitudes, and their wide range of interests (McCrae \& Costa, 1997). Correspondingly, Jackson and Poulsen (2005) found that openness was related to both frequency and quality of contact with outgroup members. Consequently, people with high, compared to low, levels of openness to experience may experience less intergroup anxiety, as they are themselves drawn to new and varied experiences (Maddi \& Berne, 1964, see McCrae \& Costa, 1997). Agreeable people report liking other people more than do their less agreeable peers (Graziano, Jensen-Campbell, \& Hair, 1996; Jensen-Campbell \& Graziano, 2001). People who like others are prone to communicate their liking to others and, hence, are liked in turn (e.g., Aronson \& Worchel, 1966; Condon \& Crano, 1988; Curtis \& Miller, 1986). Hence, they may 
also hold less negative expectations of rejection or prejudice during interactions with outgroup members. That is, they may not be concerned that the interaction partner, or oneself, may act in an inadequate or offensive manner - ultimately resulting in reduced levels of intergroup anxiety. In line with previous research, it may be this reduction in intergroup anxiety that predicts a more positive outgroup attitude (Page-Gould, Mendoza-Denton, \& Tropp, 2008; Paolini et al., 2004; Turner et al., 2007). In line with our findings in Study 1, we expect to find that extraverts will have more cross-group friends, which will in turn be associated with less anxiety and a more positive outgroup attitude.

Finally, in Study 1 we found that friendship was more strongly associated with positive outgroup attitudes among those low in agreeableness and extraversion, but not among those low in openness. In Study 2, we attempt to replicate these findings. Moreover, we conduct moderated mediation in order to examine whether any moderation effect that emerges can be explained in part by the mediating role of intergroup anxiety

\section{Method}

\section{Participants}

Participants were 160 undergraduate students at a British university, who voluntarily participated in the study. Thirteen participants were excluded, seven because they were not British and four because they were not White, while two participants were excluded due to missing data. The final sample consisted of 147 White British participants, comprising 76 women and 71 men; their mean age was 20.00 years $(\mathrm{SD}=1.75)$.

\section{Procedure}

The procedure was identical to in Study 1, aside from the inclusion of two new measures: ingroup friendship and intergroup anxiety.

\section{Questionnaires}

Predictor Variables. Number of White friends was assessed by asking participants the following question: "Please indicate how many White friends you have by circling one letter 
below." $(a=<5, b=5-10, c=10-15, d=15-20, e=>20)$. Responses were then coded from $1(a)$ to 5 (e), correspondingly. Thus, a higher number denoted more White friendships.

To assess Cross-group friendships, participants were asked the following question: "How many Asian friends do you have at university?" ( $a=$ None, $b=$ One, $c=$ Two to five, $d$ = Five to ten, $e=$ More than ten). Responses were then coded from 0 (a) to $4(e)$, correspondingly. A higher number denoted more cross-group friendships.

The BFI (John et al., 1991) was used to assess the Big Five personality factors. The extraversion items yielded a reliable scale $(\alpha=.87)$. Openness to experience $(\alpha=.68)$ yielded a value of alpha that was slightly less than the conventional value of .70 , so we excluded the item "Have an active imagination", resulting in substantially improved reliability $(\alpha=.79)$. The nine agreeableness items did not yield a reliable scale $(\alpha=.58)$, but after excluding the item "Is generally trusting", the scale comprising the remaining eight items was reliable $(\alpha=.71)$.

Mediator Variable. We used a shortened version of Stephan and Stephan's (1985) intergroup anxiety scale, reduced from 11 to six items (e.g., Turner et al., 2007). Participants read the following: "Please think of how you would feel mixing socially with complete strangers who are Asian. Please try to imagine how you would feel. If you were the only White person and you found yourself among a group of Asians, how would you feel compared to an occasion where you found yourself with only White people?" Participants then rated the extent to which they would feel "happy" (R), "awkward”, "self-conscious”, “confident” (R), "defensive", "relaxed" (R) when mixing socially with strangers who are Asian (all scales, $0=$ Not at all, $1=$ A little, $2=$ Some, $3=$ Quite, $4=$ Extremely). After reverse-coding items marked $(\mathrm{R})$, items were averaged and a reliable index of intergroup anxiety $(\alpha=.85)$ was obtained. A higher score represented more intergroup anxiety.

Criterion Variable. The same items were used to assess respondents' attitude towards Asians as in Study $1(\alpha=.87)$, with a higher score denoting a more positive attitude towards Asians. 
Socio-demographic Variables. Participants indicated their gender, age, nationality, and ethnicity.

\section{Results}

\section{Preliminary Analyses}

Means, standard deviations, and correlations between variables are reported in Table 2. Cross-group friendship was negatively correlated with intergroup anxiety, and positively correlated with outgroup attitude, while intergroup anxiety was also negatively correlated with outgroup attitude. Extraversion was significantly related to cross-group friendship, but agreeableness and openness to experience were not. In addition, agreeableness was negatively correlated with intergroup anxiety, while openness to experience showed a non-significant but negative correlation with intergroup anxiety. Both agreeableness and openness to experience were positively correlated with outgroup attitude. Lastly, number of White friendships was negatively correlated with openness to experience, and positively correlated with extraversion and cross-group friendship. It was not, however, significantly related to the remaining variables examined.

\section{Structural Equation Modelling}

As in Study 1, we created subsets of items resulting in three indicators for extraversion, agreeableness, and openness to experience, as well as for intergroup anxiety and outgroup attitude. White and cross-group friendships were assessed via one indicator. The proposed model was then tested using SEM with latent variables in LISREL. White friendships, extraversion, agreeableness, and openness to experience were entered as predictor variables, followed by cross-group friendship and intergroup anxiety, while outgroup attitude was entered as the criterion variable. We considered the association of extraversion with cross-group friendship and the associations of openness to experience and agreeableness with intergroup anxiety and outgroup attitude. The relationship between friendship and outgroup attitude was expected to be mediated by intergroup anxiety. Given that agreeableness and openness were not correlated with cross-group friendship, we did not test these paths in the model. In order to fully control for White friendships, paths from 
White friendships to cross-group friendship, intergroup anxiety, and outgroup attitude were included. The proposed structural model fit the data very well: $\chi^{2}(105)=133.82, p=.03$; RMSEA $=.043 ; \mathrm{SRMR}=.067 ; \mathrm{CFI}=.98($ see Figure 2$)$

The model shows that cross-group friendship was negatively associated with intergroup anxiety $(\beta=-.30, p<.001)$, which, in turn, was negatively associated with outgroup attitude $(\beta=-$ $.38, p<.001$; see Figure 2). In line with our expectations regarding agreeableness and openness to experience, both variables were significantly, negative associated with intergroup anxiety, $(\beta=-$ $.17, p=.05 ; \beta=-.21, p<.05$, respectively), while openness to experience also had a significant direct association with outgroup attitude $(\beta=.18, p<.05$, agreeableness: $\beta=.15$, ns). Extraversion had a significant positive association with cross-group friendship $(\beta=.25, p<.01)$. Lastly, White friendships did not have a significant relationship with cross-group friendship $(\beta=.07, \mathrm{~ns})$, intergroup anxiety $(\beta=-.09, \mathrm{~ns}$.$) , or outgroup attitude (\beta=.08, \mathrm{~ns})$. The model explained a moderate proportion of the variance in outgroup attitude $\left(\mathrm{R}^{2}=.25\right)$. In order to identify how much of the variance in outgroup attitudes is explained by personality variables on their own, we ran the model without cross-group friendship and intergroup anxiety. In this case, the variance explained was somewhat reduced $\left(\mathrm{R}^{2}=.16\right)$.

Table 3 presents the direct and indirect effects of the three personality traits and crossgroup friendship on intergroup anxiety and outgroup attitude. The estimates of the indirect effects indicated that cross-group friendship, openness to experience, and agreeableness were indirectly related to outgroup attitude through intergroup anxiety. Although this indirect effect was only marginally significant for agreeableness, it contributed to the total effect of agreeableness on outgroup attitude, which was found to be significant (see Table 3). Finally, extraversion was significantly indirectly related to intergroup anxiety and also, though very weakly, to outgroup attitude.

We also tested three alternative models to increase the confidence in our proposed model. First, we tested a model in which all possible paths between variables were included, which did not 
fit the data better than our proposed, more parsimonious model: $\chi^{2}(100)=124.57, p=.05$; $\mathrm{RMSEA}=.41 ; \mathrm{SRMR}=.058 ; \mathrm{CFI}=.98$. Second, we tested a model in which the causal order was the same as in our proposed model, except for switching the positioning of cross-group friendship and intergroup anxiety within the model. This is because past research suggests that people anxious about intergroup interactions might avoid friendships with outgroup members (Plant \& Devine, 2003). However, this model fit the data considerably worse than the proposed model: $\chi^{2}$ $(105)=158.22, p<.001 ; \mathrm{RMSEA}=.059 ; \mathrm{SRMR}=.113 ; \mathrm{CFI}=.96$

Third, we tested a model in which the paths from both Agreeableness and Openness to cross-group friendship were included. This did not significantly improve the fit of the model, $\chi^{2}$ $(103)=132.49, p=.03 ; \mathrm{RMSEA}=.044 ; \mathrm{SRMR}=.064 ; \mathrm{CFI}=.98$ and confirmed that the paths from Openness and Agreeableness to cross-group friendship were non-significant, $\beta=.09$ and,$\beta$ $=.08$, respectively. Hence, a model without these paths is more parsimonious and therefore preferred.

In sum, the results of Study 2 replicated the relationship between extraversion and crossgroup friendship, and between agreeableness and openness to experience on the one hand, and outgroup attitude on the other. In addition, the relationship between cross-group friendship and outgroup attitude was mediated by intergroup anxiety. The relationships of both agreeableness and openness with outgroup attitude were also partially mediated by intergroup anxiety. Finally, these effects emerged while controlling for the effect of (ingroup) friendships.

Moderation analyses

As in Study 1, we explored the interaction effects between the three personality factors and cross-group friendships by conducting a series of regression analyses. Again we tested the moderating role of each personality factor while controlling for the other two personality factors. White friendship was included as a control variable in these analyses.

First, we tested the moderating role of personality in the relationship between cross-group friendships and outgroup attitudes. We obtained a significant cross-group friendships $\mathrm{x}$ 
agreeableness interaction, $\beta=-.18, p<.05$, whereas the cross-group friendships $\mathrm{x}$ extraversion interaction was only marginally significant, $\beta=-.14, p=.08$. The interaction between cross-group friendships and openness was non-significant, $\beta=-.04$, ns.

Replicating the results of Study 1, simple slopes analyses indicated that cross-group friendship was significantly related to outgroup attitudes among people scoring low (1 SD below the mean) on agreeableness as well as among people scoring low on extraversion, $\beta=.28, p<.01$ and $\beta=.25, p<.05$, respectively but not among people scoring high ( $1 \mathrm{SD}$ above the mean) on agreeableness and extraversion, $\beta=-.05$, ns and $\beta=-.02, n s$., respectively. These findings are generally consistent with our hypotheses and our findings in Study 1.

Next, we tested the moderating role of the three personality factors in the relationship between cross-group friendships and intergroup anxiety. Again, the cross-group friendships $\mathrm{x}$ agreeableness interaction was significant, $\beta=.22, p<.01$, but no significant interaction effects were found for extraversion and openness, $\beta=.13$ and $\beta=.09$, ns. Cross-group friendship was significantly related to intergroup anxiety among people scoring low on agreeableness $\beta=-.45, p$ $<.001$ but not among those scoring high on agreeableness $\beta=-.04, n s$.

\section{Moderated mediation analyses}

Finally, given that a) intergroup anxiety is considered to be a mediator of the effect on crossgroup friendships on outgroup attitudes, and b) we obtained a significant interaction effect between agreeableness and cross-group friendships on both outgroup attitudes as well as intergroup anxiety, we additionally tested whether intergroup anxiety mediated the cross-group friendships $\mathrm{x}$ agreeableness moderation effect on outgroup attitudes.

As such, we estimated the conditional indirect effects (based on 5000 bootstrap samples) of cross-group friendships on outgroup attitudes through intergroup anxiety at low (1 SD below the mean) and high (1 SD above the mean) levels of agreeableness and calculated $95 \%$ bias-corrected and accelerated bootstrap confidence intervals for these conditional indirect effects. The indirect effect of cross-group friendships via intergroup anxiety was significant among respondents with 
low levels of agreeableness, $b=.19, S E=.06, \mathrm{CI}_{95 \%}=[.09, .34]$, but not among those with high levels of agreeableness, $b=.02, S E=.04, \mathrm{CI}_{95 \%}=[-.06, .11]$.

General Discussion

The present research applied personality traits of the $\mathrm{FFM}^{1}$ and the most successful situational approach, the intergroup contact hypothesis, to the study of reducing intergroup prejudice. Our findings support the situational approach to reducing prejudice, as cross-group friendship had a strong positive effect on outgroup attitude (controlling for ingroup friendships in Study 2), which was mediated by intergroup anxiety (in Study 2). This finding is in line with our hypothesis, as well as with previous findings (e.g., Paolini et al., 2004; Turner et al., 2007).

Notably, we tested our models using rigorous analyses, specifically, structural equation modeling with latent variables. Moderation analyses also demonstrated that cross-group friendship is more strongly related to positive outgroup attitudes for those low in agreeableness and extraversion. Moreover, for those lower in agreeableness, this effect can be explained by a greater reduction in intergroup anxiety. Below we summarize our findings regarding the relationship between the personality traits, cross-group friendship, intergroup anxiety, and outgroup attitude.

Openness to experience and agreeableness

In previous research, openness and agreeableness have emerged as the most reliable trait predictors of outgroup attitudes (e.g., Ekehammar \& Akrami, 2003; Sibley \& Duckitt, 2008). Our findings replicate these earlier results. Moreover, we have, for the first time, found that intergroup anxiety is an important mechanism underlying the relationships between openness and agreeableness on the one hand, and outgroup attitude on the other. This finding represents a significant extension in our understanding of the cumulative role that personality and contact factors play in explaining intergroup attitudes. Specifically, Study 2 revealed that the relationship between openness to experience and outgroup attitude was partially mediated by intergroup anxiety, while the relationship between agreeableness and outgroup attitude was fully mediated by intergroup anxiety. Both of these findings make theoretical sense. People who score high on 
openness are likely to feel less intergroup anxiety when they experience, or learn about, crossgroup friendships, as they tend to be drawn to new and varied experiences (Maddi \& Berne, 1964; see McCrae \& Costa, 1997). Agreeable individuals, on the other hand, are less likely to hold negative expectations of rejection or prejudice during interactions with outgroup members typically a major component of intergroup anxiety - because not only do they think the best of others, but they also expect others to like them in return. In turn, lowered levels of intergroup anxiety are associated with less prejudiced attitudes (e.g., Paolini et al., 2004).

We should note here that there is greater potential for shared method variance (i.e., the possibility that relationships between variables are inflated due to the use of common methods and response characteristics; see Podsakoff, MacKenzie, Lee, \& Podsakoff, 2003) in the measures of contact and attitudes, than in the measures of personality and attitudes. Nonetheless, other studies in the field give us confidence that self-report measures of contact are valid, with self-report measures of intergroup contact correlating with observer ratings of contact (Dhont, Van Hiel, De Bolle, \& Roets, in press; Hewstone, Judd, \& Sharp, 2011). Furthermore, we need to bear in mind that there are various ways in which personality and situational forces can combine (Jackson \& Poulsen, 2005). That is, the relative impact of, and the various forms of integration between, personality factors and intergroup contact situations are very likely to depend on the particular personality characteristics, the contact situations and the target groups under investigation.

It is important to acknowledge that, in contrast with Jackson and Poulsen (2005), we did not find openness to experience and agreeableness to predict intergroup contact in our structural equation models. We have identified two possible reasons for these differences. First, by using SEM, we simultaneously tested the predictive value of three predictors in Study 1 and four in Study 2, whereas Jackson and Poulsen used two separate regression analyses to test the effect of openness and agreeableness. In their analyses, there were no control variables at all and the effects of the two personality traits were tested independently from one other and without other personality traits included in the analyses. Second, our own and the studies conducted by Jackson 
and Poulsen investigated two different types of contact: Jackson and Poulsen focused on general contact quality while we have focused on cross-group friendship. Friendship is a unique, and particularly long-term and intimate, form of contact that is associated with intergroup trust and increased inclusion of other in the self (Turner et al., 2007). It may therefore be that while being open and agreeable may make us more amenable to positive contact in general, forming close friendships requires a greater degree of commitment. Indeed, it may be that, having established good quality contact, there is a greater chance that cross-group friendships will develop. Longitudinal research on personality and friendship may help to establish such an effect.

Extraversion and cross-group friendship

We also found a relationship between extraversion and cross-group friendship in both studies which emerged even when controlling for number of White friendships (Study 2). This contrasts with previous research, which has typically shown effects only for agreeableness and openness (e.g., Flynn, 2005; Jackson \& Poulsen, 1995). However, extraversion is concerned with a desire to affiliate with, and engage in friendships with, others, and is therefore is especially likely to be predictive of forms of contact that involve friendships rather than casual interactions. The findings reported in this paper provide evidence for this supposition. This finding bears important implications, as it suggests that one's personality influences the likelihood that one will engage in particular types of intergroup contact that ultimately lead to more positive attitudes. This finding suggests, for example, that for individuals who are relatively low on extraversion, and hence are less likely to form cross-group friendships, the implementation of structured contact situations that reward cooperative interdependence, or an emphasis on institutional or peer group norms encouraging intergroup experiences, might be especially influential in bringing about more positive outgroup attitudes. Efforts to stimulate a common ingroup identity might be similarly beneficial (Gaertner \& Dovidio, 2000). Hence, optimally effective contact interventions to reduce prejudice may also need to take into account individuals' personality traits, so that those individuals who are least likely to engage in beneficial intergroup encounters by themselves can be 
targeted specifically. In sum, the results of the present research regarding extraversion suggest that personality and more proximate situational factors most likely work together in exerting beneficial intergroup effects, ultimately leading to more positive outgroup attitudes.

Personality as a moderator of the friendship - attitude relationship

We tested the hypothesis that cross-group friendship might be more strongly associated with positive outgroup attitudes for those low in agreeableness, extraversion, and openness. We found partial support for this hypothesis. Specifically, we found that those low in extraversion and agreeableness showed a stronger positive relationship between cross-group friendships and outgroup attitude across both studies, however no differences emerged in the effectiveness of contact for those low versus high in openness. These findings provide some initial support for the idea that those with personality traits associated with lower levels of contact and higher levels of prejudice have more to gain from intergroup contact, and are therefore more likely to show reductions in prejudice (e.g., Al Ramiah \& Hewstone, 2012' Dhont \& Von Hiel, 2009). The findings are also consistent with Dhont and Von Hiel, and Hodson (2008) who found similar moderating effects on contact of RWA and SDO. Study 2 also revealed that the indirect effect of cross-group friendship via intergroup anxiety was significant among respondents with low levels of agreeableness, but not among those with high levels of agreeableness. This suggests that those low in agreeableness are more likely to be anxious, and therefore more likely to benefit from the anxiety reducing properties of cross-group friendship. It is intriguing that openness did not moderate the strength of the friendship - outgroup attitude relationship, and it is important that further research is carried out in order to identify why this is the case.

\section{Limitations and Future Research}

Notwithstanding the consistent evidence accrued over two studies, three main limitations of this research should be acknowledged, and some priorities for future research outlined. Firstly, caution is required when making causal inferences from cross-sectional data (MacCallum \& Austin, 2000). Nevertheless, regarding the causal direction from contact to attitudes, experimental 
(e.g., Ensari \& Miller, 2002) and longitudinal (e.g., Levin et al., 2003; Dhont et al., in press; Swart et al., 2011) analyses have supported the stronger causal direction from contact to attitudes, although longitudinal studies have also provided evidence of a self-selection bias (e.g., Binder et al., 2008; Levin et al., 2003). An extensive meta-analysis of intergroup contact studies also indicated a larger effect size between contact and prejudice for studies in which participants had no choice but to engage in contact, compared to when they had a choice (Pettigrew \& Tropp, 2006).

Secondly, as pointed out in the introduction, previous studies have linked personality or ideological beliefs with prejudice through the FFM, or RWA and SDO (e.g., Asbrock, Sibley, \& Duckitt, 2010; Ekehammar \& Akrami, 2003; Van Hiel \& Mervielde, 2005). However, it should also be noted that recent attempts have been made to integrate the interrelationships between personality, ideological beliefs, and prejudice. Ekehammar, Akrami, Gylje, and Zakrisson (2004) proposed a causal order in which the Big Five factors first affect SDO and RWA as intermediate or transmitting variables, which in turn affect prejudice. Indeed, they found that prejudice was affected indirectly by extraversion, openness to experience, and conscientiousness through RWA, and by agreeableness through SDO. Supporting this idea, a meta-analysis of 71 studies into the relationships between the FFM, RWA, SDO and prejudice by Sibley and Duckitt (2008) showed that low openness to experience and, to a lesser extent, high conscientiousness predicted RWA. Moreover, the relationship between openness to experience and prejudice was mediated by RWA. Low agreeableness was the most powerful predictor of SDO, and the relationship between low agreeableness and prejudice was also mediated by SDO, supporting a dual route model from personality to prejudice, via ideology (Duckitt, 2001; Duckitt \& Sibley, 2010). Researchers have also recently begun to examine the role of RWA and SDO within the framework of intergroup contact and cross-group friendships (e.g., Dhont \& Van Hiel, 2009; 2011; Hodson, 2008; Hodson et al., 2009), but these studies did not consider the role of core personality traits. Future research may therefore want to expand the results of the present research by including FFM measures alongside RWA and SDO in examining their impact on the relationship between cross-group 
friendship and outgroup judgements.

Third, we did not focus on all of the FFM constructs in the current research, instead choosing to focus on extraversion, agreeableness, and openness. This is because for each of these three variables, there was strong theoretical and empirical reasons to believe that they would play an important role in friendship, its outcomes and mediators. Although we did measure conscientiousness and neuroticism in both studies, as expected neither emerged as consistent predictors of our key measures of interest and they were therefore removed from subsequent analysis.

\section{Conclusion}

Since the general premise that personality and situational forces most often combine in various ways in bringing about psychological outcomes or behaviour (e.g., Ickes et al., 1997; Kenrick \& Funder, 1988), there has been very little integration of dispositional and contextual factors in research on intergroup contact (see also Jackson \& Poulsen, 2005). Through our integration of personality factors with intergroup contact theory, we have shown that the beneficial effects of cross-group friendship can be examined more closely by assessing the influence of one on the other, and making inferences about their respective impact on reducing prejudice. In sum, the present research represents advances over prior work on intergroup contact in three main ways. First, we showed that extraversion positively influences the likelihood of forming cross-group friendships, even when controlling for number of ingroup friendships, with knock on effects for intergroup anxiety and outgroup attitudes. Second, we showed that agreeableness and openness to experience can exert positive influences on outgroup attitudes, either directly, or indirectly via intergroup anxiety, although these effects are relatively weak compared to the effects of crossgroup friendships. Third, we demonstrated that cross-group friendship is especially predictive of more positive intergroup attitudes those low in extraversion and agreeableness, with those low in agreeableness benefiting particularly from lowered intergroup anxiety as a result of cross-group friendship. 


\section{References}

Adorno, T. W., Frenkel-Brunswick, E., Levinson, D. J., \& Stanford, R. N. (1950). The authoritarian personality. New York: Harper \& Row.

Akrami, N., Ekehammar, B., \& Yang-Wallentin, F. (2011). Personality and social psychology factors explaining sexism. Journal of Individual Differences, 32, 153-160.

Al Ramiah, A., \& Hewstone, M. (2012). 'Rallying around the flag' Can an intergroup contact intervention promote unity? British Journal of Social Psychology,

Allport, G. W. (1954). The nature of prejudice. Cambridge/Reading, MA: Addison-Wesley.

Altemeyer, B. (1988). Enemies of Freedom: Understanding right-wing authoritarianism. San Francisco: Jossey-Bass.

Aronson, E., \& Worchel, P. (1966). Similarity versus liking as determinants of interpersonal attractiveness. Psychonomic Science, 5, 157-158.

Asbrock, F., Christ, O., Duckitt, J., \& Sibley, C. G. (2012). Differential effects of intergroup contact for authoritarians and social dominators: A dual process model perspective. Personality and Social Psychology Bulletin, 38, 477-490.

Asbrock, F., Sibley, C. G., \& Duckitt, J. (2010). Right-wing authoritarianism and social dominance orientation and the dimensions of generalized prejudice: A longitudinal test. European Journal of Personality, 24, 324-340.

Bagozzi, R. P., \& Heatherton, T. F. (1994). A general approach to representing multifaceted personality constructs: Application to state self-esteem. Structural Equation Modeling, 1, 3567.

Binder, J., Zagefka, H., Brown, R., Maquil, A., Demoulin, S., \& Leyens, J-P. (2008). Does contact reduce prejudice or does prejudice reduce contact? A longitudinal test of the contact hypothesis among majority and minority groups in three European countries. Journal of Personality and Social Psychology, 94, 843-856.

Brown, R. \& Hewstone, M. (2005). An integrative theory of intregroup contact. In M. Zanna (Ed.), 
Advances in experimental social psychology (Vol. 37, pp. 255-343). San Diego, CA: Elsevier Academic Press.

Buss, D.M. (1989). Conflict between the sexes: Strategic interference and the evocation of anger and upset. Journal of Personality and Social Psychology, 56, 735-747.

Condon, J. W., \& Crano, W. D. (1988). Inferred evaluation and the relation between attitude similarity and interpersonal attraction. Journal of Personality and Social Psychology, 54, $789-797$.

Cronbach, L. J. (1986). Balancing the qualitative and the quantitative in psychological research. Evalucion Psicologica, 2, 3-12.

Curtis, R. C., \& Miller, K. (1986). Believing another likes or dislikes you: Behaviors making the beliefs come true. Journal of Personality and Social Psychology, 51, 284-290.

Davies, K., Tropp, L.R., Aron, A., Pettigrew, T.F., \& Wright, S.C. (2011). Cross-group friendships and intergroup attitudes: A meta-analytic review. Personality and Social Psychology Review, $15,332-351$.

Dhont, K., \& Van Hiel, A. (2009). We must not be enemies: Interracial contact and the reduction of prejudice among authoritarians. Personality and Individual Differences, 46, 172-177.

Dhont, K., Van Hiel, A., De Bolle, M., \& Roets, A. (in press). Longitudinal intergroup contact effects on prejudice using self- and observer-reports. British Journal of Social Psychology. doi: 10.1111/j.2044-8309.2011.02039.x

Duckitt, J. (2001). A dual-process cognitive-motivational theory of ideology and prejudice. Advances in Experimental Social Psychology, 33, 41-113.

Duckitt, J., \& Sibley, C. G. (2010). Personality, ideology, prejudice, and politics: A dual-process motivational model. Journal of Personality, 78, 1861-1894.

Duriez, B., \& Van Hiel, A. (2002). The march of modern fascism: A comparison of social dominance orientation and authoritarianism. Personality and Individual Differences, 32, 1199-1213. 
Eddy. G., \& Sinnett, E. (1973). Behavior setting utilization by emotionally disturbed college students. Journal of Consulting and Clinical Psychology, 40, 210-216.

Ekehammar, B., \& Akrami, N. (2003). The relation between personality and prejudice: A variableversus a person-centred approach. European Journal of Personality , 17, 449-464.

Ekehammar, B., Akrami, N., Gylje, M., Zakrisson, I. (2004). What matters most to prejudice: Big Five personality, Social Dominance Orientation or Right-Wing Authoritarianism? European Journal of Personality, 18, 463-482.

Ensari, N., \& Miller, N. (2002). The outgroup must not be so bad after all: The effects of disclosure, typicality, and salience on intergroup bias. Journal of Personality and Social Psychology, 83, 319-329.

Flynn, F. J. (2005). Having an open mind: The impact of openness to experience on interracial attitudes and impression formation. Journal of Personality and Social Psychology, 88, 816826.

Gaertner, S. L., \& Dovidio, J. F. (2000). Reducing intergroup bias: The common ingroup identity model. Philadelphia: Psychology Press.

Goldberg, L. R. (1992). The development of markers for the Big-five factor structure. Psychological Assessment, 4, 26-42.

Goldberg, L. R., \& Kilkowski, J. M. (1985). The prediction of semantic consistency in selfdescriptions: Characteristics of persons and of terms that affect the consistency of responses to synonym and anonym pairs. Journal of Personality and Social Psychology, 48, 82-98.

Graziano, W.G., Jensen-Campbell, L. A., \& Hair, E. C. (1996). Perceiving interpersonal conflict and reacting to it: The case for agreeableness. Journal of Personality and Social Psychology, $70,820-835$.

Hewstone, M., Judd, C. M., \& Sharp, M. (2011). Do observer ratings validate self-reports of intergroup contact. Journal of Experimental Social Psychology, 47, 599-509.

Hodson, G. (2008). Interracial prison contact: The pros for (socially dominant) cons. British 
Journal of Social Psychology, 47, 325-351.

Hodson, G. (2009). The puzzling person-situation schism in prejudice research. Journal of Research in Personality, 43, 247-248.

Hodson, G., Harry, H., \& Mitchell, A. (2009). Independent benefits of contact and friendship on attitudes towards homosexuals among authoritarians and highly identified heterosexuals. European Journal of Social Psychology, 39, 509-525.

Hu, L., \& Bentler, P. M. (1999). Cutoff criteria for fit indexes in covariance structure analysis: Conventional criteria versus new alternatives. Structural Equation Modeling, 6, 1-55.

Ickes, W., Snyder, M. \& Garcia, S. (1997). Personality influences on the choice of situations. In R. Hogan, J.A. Johnson, \& S. Briggs (Eds.), Handbook of personality psychology, (pp. 165195). San Diego: Academic Press.

Jackson, J. W., \& Poulsen, J. R. (2005). Contact experiences mediate the relationship between five-factor model personality traits and ethnic prejudice. Journal of Applied Social Psychology, 35, 667-685.

Jensen-Campbell, L. A., \& Graziano, W. G. (2001). Agreeableness as a moderator of interpersonal conflict. Journal of Personality, 69, 323-362.

John, O. P., Donahue, E. M., \& Kentle, R. L. (1991). The Big Five Inventory--Versions 4a and 54. Berkeley, CA: University of California, Berkeley, Institute of Personality and Social Research.

Kenrick, D. T., \& Funder, D. C. (1988). Profiting from controversy: Lessons from the person x situation debate. American Psychologist, 43, 23-34.

Levin, S., van Laar, C., \& Sidanius, J. (2003). The effects of ingroup and outgroup friendships on ethnic attitudes in college: A longitudinal study. Group Processes and Intergroup Relations, 6, 76-92.

Little, T. D., Cunningham, W. A., Shahar, G. \& Widaman, K. F. (2002). To parcel or not to parcel: Exploring the question, weighing the merits. Structural Equation Modeling, 9, 151-173. 
Mackie, D. M., \& Smith, E. R. (1998). Intergroup relations: Insights from a theoretically integrative approach. Psychological Review, 105, 499-529.

MacCallum, R. C., \& Austin, J. T. (2000). Applications of structural equation modeling in psychological research. Annual Review of Psychology, 51, 201-226.

Maddi, S. R., \& Berne, N. (1964). Novelty of productions and desire for novelty as active and passive forms of the need for variety. Journal of Personality, 22, 270-277.

McCrae, R. R., \& Costa, P. T. (1997). Conceptions and correlates of Openness to Experience. In R. Hogan, J. Johnson \& S. Briggs (Eds), Handbook of personality psychology (pp. 825-847). San Diego: Academic Press.

McCrae, R. R., \& Costa, P. T., Jr. (1999). A Five-Factor theory of personality. In L. A. Pervin \& O. P. John (Eds.), Handbook of personality: Theory and research (2nd ed.) (pp. 139-153). New York, NY: Guilford Press.

Page-Gould, E., Mendoza-Denton, R., \& Tropp, L. R. (2008). With a little help from my crossgroup friend: Reducing anxiety in intergroup contexts through cross-group friendship. Journal of Personality and Social Psychology, 95, 1080 - 1094.

Paolini, S., Hewstone, M., Cairns, E., \& Voci, A. (2004). Effects of direct and indirect cross-group friendships on judgements of Catholics and Protestants in Northern Ireland: The mediating role of an anxiety-reduction mechanism. Personality and Social Psychology Bulletin, 30, 770-786.

Pettigrew, T. F. (1997). Generalized intergroup contact effects on prejudice. Personality and Social Psychological Bulletin, 23, 173-185.

Pettigrew, T. F. (2008). Future directions for intergroup contact theory and research. International Journal of Intercultural Relations, 32, 187-199.

Pettigrew, T. F., \& Tropp, L. (2006). A meta-analytic test of intergroup contact theory. Journal of Personality and Social Psychology, 90, 751-783.

Pettigrew, T. F., and Tropp, L. R. (2008). How does contact reduce prejudice? A meta-analytic test 
of three mediators. European Journal of Social Psychology, 38, 922-934.

Podsakoff, P. M., MacKenzie, S. B., Lee, J., \& Podsakoff, N. P. (2003). Common method biases in behavioral research: A critical review of the literature and recommended remedies. Journal of Applied Psychology, 88, 879-903.

Pratto, F., Sidanius, J., Stallworth, L. M., \& Malle, B. F. (1994). Social dominance orientation: A personality variable predicting social and political attitudes. Journal of Personality \& Social Psychology, 67, 741-763.

Prestwich, A., Kenworthy, J., Wilson, M., \& Kwan-Tat, N. (2008). Differential relations between two types of contact and implicit and explicit racial attitudes. British Journal of Social Psychology, 47, 575-588.

Sengupta, N. K., Barlow, F. K., \& Sibley, C. G. (2012). Intergroup contact and post-colonial ideology: Outgroup contact ameliorates symbolic exclusion but not historical negation. International Journal of Intercultural Relations, 36, 506-517.

Sibley, C. G., \& Duckitt, J. (2008). Personality and prejudice: A meta-analysis and theoretical review. Personality and Social Psychology Review, 12, 248-279.

Swart, H., Hewstone, M., Christ, O., \& Voci, A. (2011). Affective mediators of intergroup contact: A longitudinal analysis in South Africa. Journal of Personality and Social Psychology, 101, $1221-1238$.

Stephan, W. G., \& Stephan, C. W. (1985). Intergroup anxiety. Journal of Social Issues, 41, 157176.

Stephan, W. G., Diaz Loving, R., \& Duran, A. (2000). Integrated threat theory and intercultural attitudes: Mexico and the United States. Journal of Cross Cultural Psychology, 31, 240-249.

Turner, R. N., Hewstone, M., \& Voci, A. (2007). Reducing explicit and implicit prejudice via direct and extended contact: The mediating role of self-disclosure and intergroup anxiety. Journal of Personality and Social Psychology, 93, 369-38. 
Van Hiel, A., \& Mervielde, I. (2005). Authoritarianism and social dominance orientation: Relationships with various forms of racism. Journal of Applied Social Psychology 35, 2323-2344.

Wilder, D. (1993). The role of anxiety in facilitating stereotypic judgements of outgroup behaviour. In D. M. Mackie \& D. L. Hamilton (Eds.), Affect, cognition, and stereotyping: Interactive processes in group perception (pp. 87-109). San Diego, US: Academic Press.

Wilder, D., \& Simon, A. F. (2001). Affect as a cause of intergroup bias. In R. Brown \& S.L. Gaertner (Eds.), Blackwell handbook of social psychology: Intergroup processes (pp. 153172). Malden, MA: Blackwell.

Wright, S. C., Aron, A., McLaughlin-Volpe, T., \& Ropp, S. A. (1997). The extended contact effect: Knowledge of cross-group friendships and prejudice. Journal of Personality and Social Psychology, 73, 73-90. 


\section{Footnote}

${ }^{1}$ Given that neuroticism and conscientiousness are not thought to be powerful predictors of intergroup contact or prejudice, we chose not to focus on them in the current research.

Nonetheless, both of these personality factors were also measured in both studies. The results were as follows. Reliability was good for both neuroticism (Study 1: $\alpha=.85$; Study $2 \alpha=.87$ ) and conscientiousness (Study 1: $\alpha=.85$; Study 2: $\alpha=.81$ ) across both studies. In line with our assumptions, conscientiousness was not significantly related to cross-group friendship (Study 1, r $=-.10 ;$ Study 2, $r=.03$ ), to outgroup attitudes (Study 1, r = -.10; Study 2, $r=.03$ ), or to intergroup anxiety (Study 2, r = -.03). For neuroticism, a significant negative relationship was found with cross-group friendships in Study $1(\mathrm{r}=-.22, \mathrm{p}<.01)$ but this relationship was not replicated in Study $2(r=-.05, \mathrm{~ns})$. Moreover, including a latent factor of neuroticism to predict cross-group friendship in the path model of Study 1 revealed that this path was not significant $(\beta=-.16, \mathrm{~ns})$. Also the relationships of neuroticism with outgroup attitudes (Study 1, r = .03; Study 2, $\mathrm{r}=.12$ ) and intergroup anxiety (Study $2, \mathrm{r}=-.01$ ) were not significant. 
Table 1

Means, Standard Deviations, Reliability and Correlations between Variables (Study 1)

\begin{tabular}{|c|c|c|c|c|c|c|c|c|}
\hline & Mean & SD & $\alpha$ & 1 & 2 & 3 & 4 & 5 \\
\hline 1. Agreeableness & 3.64 & .60 & .77 & 1.00 & & & & \\
\hline 2. Openness to experience & 3.80 & .65 & .83 & .03 & 1.00 & & & \\
\hline 3. Extraversion & 3.49 & .73 & .86 & .04 & $.30^{* * * *}$ & 1.00 & & \\
\hline 4. Cross-group friendship & 2.90 & .92 & & $.14^{(*)}$ & .13 & $.23^{* *}$ & 1.00 & \\
\hline 5. Outgroup attitude & 4.84 & .87 & .92 & $.17^{*}$ & $.18^{*}$ & .09 & $.27^{* * *}$ & 1.00 \\
\hline
\end{tabular}


Table 2

Means, Standard Deviations, Reliability and Correlations between Variables (Study 2)

\begin{tabular}{lcccccccccc}
\hline & Mean SD & $\alpha$ & 1 & 2 & 3 & 4 & 5 & 6 & 7 \\
\hline 1. White friendships & 4.33 & 1.04 & & 1.00 & & & & & \\
2. Agreeableness & 3.63 & .62 & .71 & -.02 & 1.00 & & & & \\
3. Openness to experience & 3.80 & .60 & .79 & $-.20 *$ & -.03 & 1.00 & & & \\
4. Extraversion & 3.44 & .78 & .87 & $.39 * *$ & .12 & .04 & 1.00 & & \\
5. Cross-group friendship & 2.73 & .94 & & $.17^{*}$ & .09 & .12 & $.28^{* *}$ & 1.00 & \\
6. Intergroup anxiety & 1.59 & .80 & .85 & -.09 & $-.18^{*}$ & $-.13^{\text {(* }}-.17^{* *}-.33^{* *} 1.00$ & \\
7. Outgroup attitude & 5.04 & .99 & .87 & .07 & $.20^{*}$ & $.19^{*}$ & -.02 & $.17^{* *}-.46^{* *}$ & 1.00 \\
\hline
\end{tabular}

(*) $p \leq .10 ; * p<.05 ; * * p<.01 ; * * * \mathrm{p}<.001 ; N=147$ 
Table 3.

Table of effects decomposition (Study 2)

\begin{tabular}{|c|c|c|c|c|c|c|}
\hline & \multicolumn{3}{|c|}{ Intergroup anxiety } & \multicolumn{3}{|c|}{ Outgroup attitude } \\
\hline & $\begin{array}{l}\text { Direct } \\
\text { effect }\end{array}$ & $\begin{array}{c}\text { Indirect } \\
\text { effect }\end{array}$ & $\begin{array}{l}\text { Total } \\
\text { effect }\end{array}$ & $\begin{array}{l}\text { Direct } \\
\text { effect }\end{array}$ & $\begin{array}{c}\text { Indirect } \\
\text { effect }\end{array}$ & $\begin{array}{l}\text { Total } \\
\text { effect }\end{array}$ \\
\hline Extraversion & l & $-.07^{*}$ & $-.07^{*}$ & l & $.03^{*}$ & $.03^{*}$ \\
\hline Openness & $-.21^{*}$ & l & $-.21^{*}$ & $.18^{*}$ & $.08^{*}$ & $.26^{* *}$ \\
\hline Agreeableness & $-.17^{*}$ & l & $-.17^{*}$ & .15 & $.07^{(*)}$ & $21^{*}$ \\
\hline Cross-group friendship & $-.30^{* * *}$ & / & $-.30^{* * *}$ & l & $.11^{* *}$ & $.11^{* *}$ \\
\hline
\end{tabular}

Note. ${ }^{(*)} p<.10 ;{ }^{*} p \leq .05 ;{ }^{* *} p<.01 ;{ }^{* * *} p<.001$ 


\section{Figure Captions}

Figure 1. Path model of the relationships between openness to experience, extraversion, and agreeableness, and cross-group friendship and outgroup attitude (Study 1).

Note. Standardized path coefficients are shown. Curved paths denote correlations between variables. Dotted lines denote non-significant paths.

$* p<.05 ; * * p<.01 ; * * * p<.001 ; N=142$.

Figure 2. Path model of the relationship between openness to experience, extraversion, and agreeableness on the one hand, and cross-group friendship, intergroup anxiety, and outgroup attitude on the other, while controlling for ingroup friendships (Study 2).

$p<.05 ; * * p<.01 ; * * * p<.001 ; N=147$. Dotted lines denote non-significant paths. 


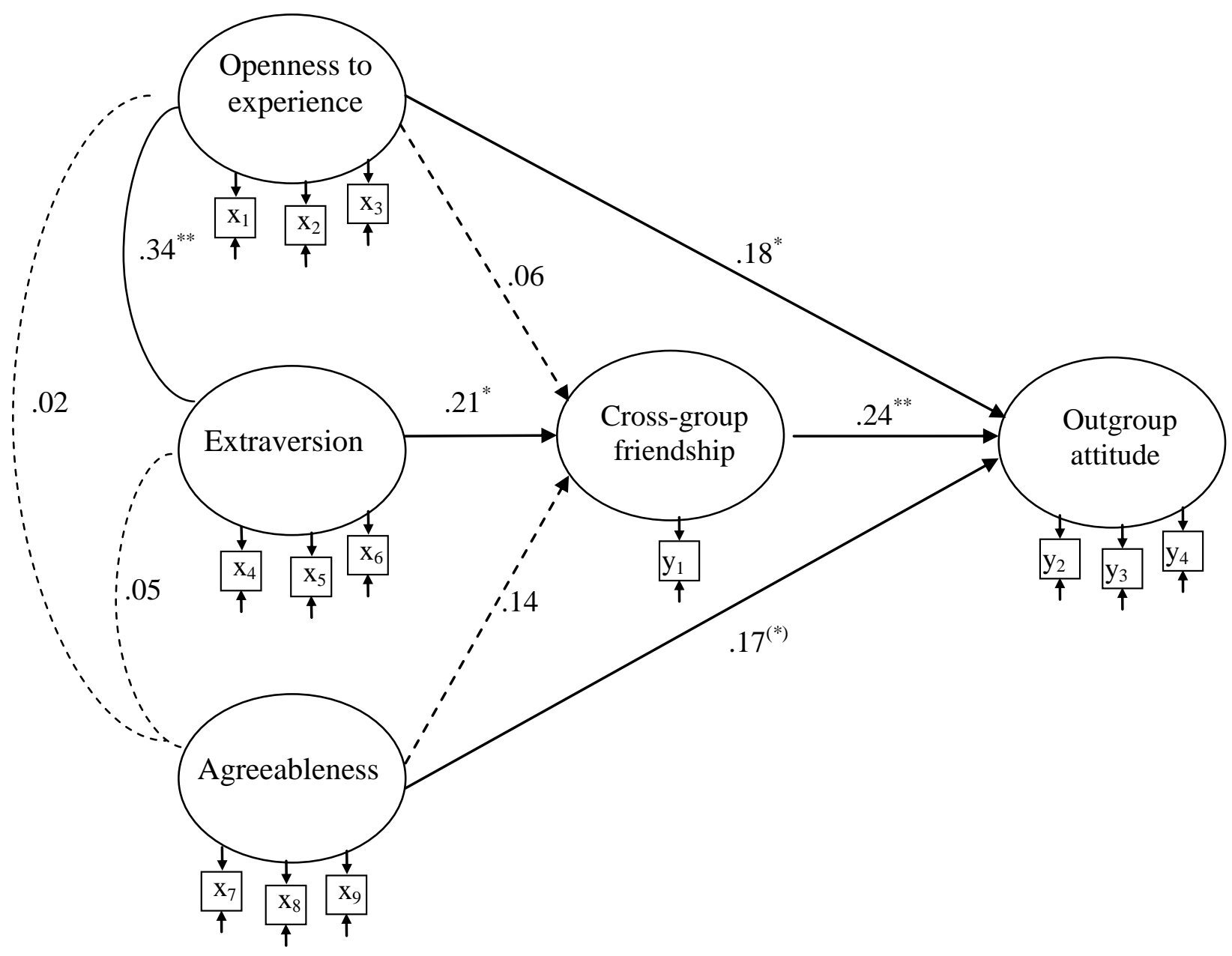




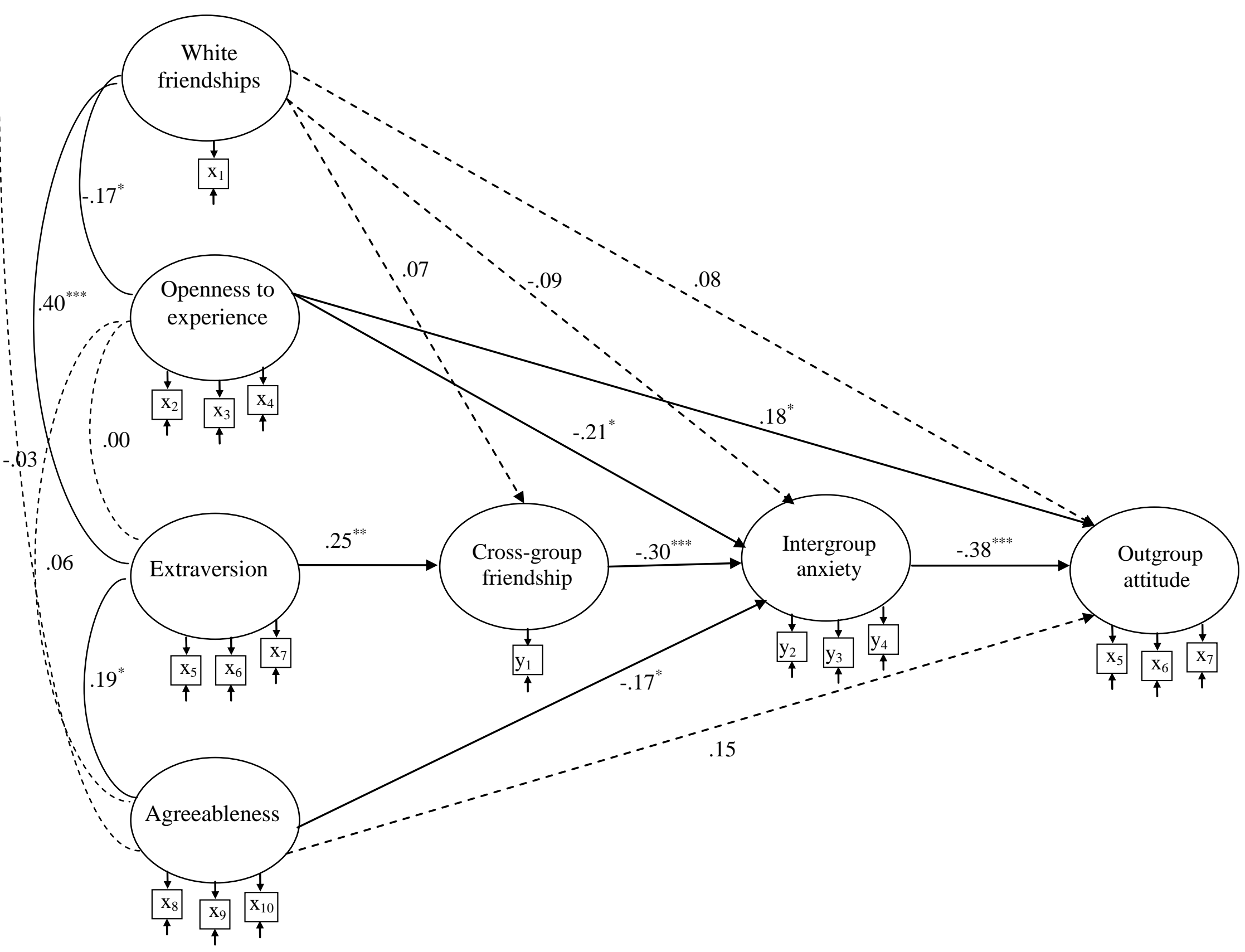

